\title{
Nativism versus nationalism and populism - bridging the gap
}

\author{
dr hab. prof. UO Rafał RIEDEL
}

\begin{abstract}
This paper identifies the major similarities and differences that nativism shares with nationalism (predominantly its economic dimension) and populism. By doing it, this study contributes to overcoming of one of the major obstacles of this realm of scholarly literature which very often confuses and conflates the three concepts. The author claims that, even though they are more similar then different, nativism has its distinctive features that stem from its origins, evolution and contemporary ways of manifestation. Due to its illiberal, exclusivist and prejudice-driven nature, nativism constitutes a dangerous ideology, which intertwines with nationalism and populism in a potentially explosive mixture. The theoretical deliberations are illustrated with the exemplifications of nativist politics in Central Europe.
\end{abstract}

\section{Keywords}

nativism, economic nationalism, ethnic populism, Central Europe

\section{Introduction}

Nativism, nationalism and ethnically based populism are very often confused and conflated. Regardless of the identified differences, they are more similar than different. They intertwine, together with other neighbouring concepts, like racism or xenophobia, in a process of producing and reproducing the industry of fear, prejudice and suspicion. In order to avoid the conceptual chaos, this paper attempts to order and map the three concepts and identify their common and differentiating elements.

This paper sees nativism as a dangerous and aggressive ideology that is rooted in racism and populism as well as it manifests itself in various incarnations, most often and recently as nationalism. On the surface nativism seems to be a moderate and politically correct ideology (close to localism and patriotism) in times of outright nationalist and racist contestation. However looking at the origins and essence of nativism, this paper argues that it uses populist tactics and offers a masking clothing to the ideology of nationalism.

The Central European region (understood predominantly as the Visegrad Countries, or V4: Poland, Hungary and the Czech and Slovak Republics) seems to be an illustrative example 
of the evolving problem of nativism due to the trajectory which these states - their populations and elites - took in the recent years. After the "return to Europe" era dominated by cosmopolitan attitudes of most of the above-mentioned societies, the nationalist and xenophobic sentiments come back to the mainstream of the Central European politics. This can be observed in many policy spheres, from refugee crisis and migration policy, through various dimensions of economic nationalism, up to the growing wave of Euroscepticism.

The paper proceeds as follows: in the first section it reconstructs the origins and basic understandings of nativism. This part is predominantly rooted in political science and history, but it also borrows from other disciplines (like psychology) that cover the problematic of nativism. It offers the scholarly recognised definitions of nativism and put them into the historical context. The next section tries to look into the phenomenon of populism in order to show its similarities and differences with nativism. From the early XX century writings up to the most contemporary times, it offers a brief review of the most common ways of understanding populism. This allows identify its vital components, mechanisms and manifestations of populism which potentially intertwine with nativism. The third section focuses on nationalism, since however it is such a rich ideological discourse, it looks predominantly at its economic realm which relates to the economic origins of earlier discussed populism and nativism. Finally, in its conclusive part, the article identifies the major similarities and differences that nativism shares with populism and nationalism.

\section{Nativism - the origins and basic understanding}

Nativism has clearly and distinctly American origins. And, surprisingly - taking into account the migration-driven composition of the American society - nativism arose, in its culmination point, as the reaction to the massive wave of migrants from Europe up to 1920s. Nativism gained its name from the native Americans, however it did not have anything to do with the indigenous American Indians but rather the inhabitants of the original Thirteen Colonies. It origins reach XVIII and XIX century and over the course of time, nativism evolved in a chameleonic fashion - it had its anti-Catholic phase in XIX century, or then anti-German phase at the break of the XIX and XX centuries. The Tea Party as an organisation or Donald Trump as a person may be successfully considered to be the XXI century manifestations of the American nativist thinking. They represent the most direct opposition to immigration-friendly policies, which - in their opinion - threaten to transform the American society. As such, nativism is one of the most important elements building American nationalism.

The definition of nativism is deeply rooted in populist logic. It is an ideology which holds that non-native elements - persons, institutions, norms or ideas - are fundamentally threatening to the homogenous "people"..$^{1}$ It is a belief that protects the interests of local inhabitants over those that migrate to the land. Politically speaking it is a position supporting a favoured status for the established inhabitants (a nation, religion, linguistic community, etc.) as compared to the claims of newcomers.

1 MUDDE, Cas: The Populist Zeitgeist, in: Government and Opposition, 39, 2004, 4, 542-543. 
Nativism is an intense opposition towards an internal minority on the ground of its foreign connections. ${ }^{2}$ Distinguishing between natives and non-natives makes nativism an ideology that is a close neighbour to nationalism and ethnically based populism. Nativism inspires systematic discriminatory actions and sentiments, including restrictive immigration policies and laws, increase in riots and hate crimes, and the rise of nativist organisations. ${ }^{3}$

Nativism is a subject of scholarly investigation also in other scientific disciplines. Psychologically speaking, nativism contends that the most of the people's developmental acquisitions have their roots in the inborn biological structure of the human body. Nativists claim that the human mind is hard-wired into the genetic make-up (like the nativist theory of language learning by Noam Chomsky). It conceives human features and behaviours are much more genetically based than culturally based. In a nutshell, primordialistically speaking, we become who we are due to the predetermined genetic program. ${ }^{4}$

This way of understanding nativism strongly refers to ethnocentric beliefs, but politically defined nativism does not have to be built on ethnic or racist fundament. The natives as imagined community can be based on the nationality, religion, language, historical legacies, or any other element that constitutes "our way of life". Therefore, in a moderate way, it also means a return to or emphasis on indigenous customs (anti-modernisation), in opposition to outside influence. That is the essence of nativism understood as the "common sense" and here it connects directly to the ideology of populism (hegemony of the natives). It demonises the aliens (especially the illegal ones) and brings the dominance of the native religion, language, and narratives.

Obviously nativism is an ideology based on nationalist sentiments separating natives from the foreigners. ${ }^{5}$ It is married to defensive nationalism (usually of economic nature) and it is built in contrast to cosmopolitanism or even neoliberalism. Nativism is by definition illiberal, but not always racist, it can be based on religion, or any other element important for the natives. Nativism includes both racist and nonracist arguments, showing that exclusion of groups can be made on cultural or religious background as well as ethnicity.

\section{Populist origins of nativism}

The backward-looking ideas of contemporary nativists date back to the origins of agrarian populism promoting the saving of small farm agriculture as the backbone of the economy and society. Populism, as a political idea, is regarded to exist already in nineteenth century (agrarian populism in USA or Russian narodnichestvo). The origins of populism itself were economic in nature - it was the political ideology of agrarian radicalism (People's Party in USA) and its concept of "cooperative society" that proposed more "fair" economic redistribution of wealth in XIX America. By attacking inequalities in income, assets, and consequently influence they drew the first economic populist program of the "authentic Americans". The other was at that time the enemies of the "ordinary people": the bank-

2 HIGHAM, John: Strangers in the Land: Patterns of American Nativism 1860-1925, New Brunswick 1955.

3 LIPPARD, Cameron: Racist Nativism in the $21^{\text {st }}$ Century, in: Sociology Compass, 5, 2011, 7, $591-606$.

4 DJERIOUAT, Hakim - TREMOLIERE, Bastien: We are made, not born: Empiricism is existentially useful, in: Motivation and Emotion, 38, 2014, 4, 529-539.

5 KNOBEL, Dale: America for Americans: The Nativist Movement in the United states, New York 1996. 
ers (including funds, investors, and so on) and industrialists (including corporations, stock companies and so on). The non-aristocratic character of the American elite was not a problem for the populists as they quickly invented terms like "money aristocracy" which holds effective until today. ${ }^{6}$ It is surprising how the early industrialist era slogans are valid at the beginning of the XXI century: national healthcare system, eight-hour working time, obligatory unemployment and health insurance.

One of the first analytical works on populism appeared in 1928 in "The American Economic Review" where John D. Black published his article on "The McNary-Haugen Movement". He discussed political and economic aspects of the relations between the agricultural sector and commerce and industry. This field of analysis correlates very well with the populist ideology from the agrarian revolt in USA in 1890s and the accompanying concept of the two nations: the nation of the producers (the exploited) and the nation of the well-to-do elites. This distinction gave birth to the political cleavage present in populist politics that is the confrontational relation between the authentic people and the parasitical elite.

In general understanding populism is a set of ideas or argumentation that is catchy and attractive based on emotional and irrational grounds, longing for simple solutions to complicated problems and directly connected to the will of the majority. It very often manifests itself in simplistic equalising democracy with unlimited will of the majority (tyranny of majority thesis). Populists claim that the majority is by democratic logic "right" and must be respected. A populist politician gladly uses negative society's mood of discontent and claims to be the spokesman of the unsatisfied.

Despite a rich interdisciplinary discourse, students of populism still disagree not only how to explain it but more fundamentally - about what it is. We seem to be witnessing a conceptual cacophony. For Jansen ${ }^{7}$ a political project is populist when it is a sustained, largescale political project that mobilizes ordinary marginalized social sectors into publicly visible and contentious political action, while articulating an anti-elite, nationalistic rhetoric that valorises ordinary people. Because of that, it is difficult to imagine democratic politics without populism. The domination of predominantly anti-populist logic - consciously or unconsciously, intentionally or unintentionally - may reduce politics to an administrative enterprise with over proportionate input from colleges of experts and technocrats (depoliticised democracy, post-democracy). ${ }^{8}$

For Jan-Werner Mueller, populism is a particular moralistic imagination of politics, a way of perceiving the political world which places in opposition a morally pure and fully unified people against small minorities, elites in particular (who are placed outside of the authentic people). ${ }^{9}$ The populists claim that only they can properly represent the proper people (the proper people extracted from the people). The moralist component of this definition highly depends on the distinguishing the moral from the immoral. And the criterion for this

6 MUELLER, Jan-Werner: Parsing populism. Who is and who is not a populist these days?, in: Juncture, 22, 2015, 2, 80-89.

7 JANSEN, Robert S.: Populist Mobilisation: A New Theoretical Approach to Populism, in: Sociological Theory, $29,2011,2,82$.

8 STAVRAKAKIS, Yannis: The Return of the "People": Populism and Anti-Populism in the Shadow of the Europea Crisis, in: Constelations, 21, 2014, 4, 505-517.

9 MUELLER, 83. 
is often manipulated by the populist politicians. In the face of a passive political culture, in which very few citizens take an active role in politics, the extracted people may sum up to an actual minority - well organised minority. Populist politicians, acting in the name of the people, may in fact oppress the majority under the moralising flag of radical democracy. The most recognised and cited contemporary researcher of populism, Cas Mudde, defines it as a thin-centred ${ }^{10}$ ideology that focuses on the antagonism between people and elites against the backdrop of popular sovereignty. Such conceptualisation has become the dominant position in the literature. ${ }^{11}$ It considers society to be ultimately divided into two homogenous and antagonistic groups "the pure people" and "the corrupt elite"12 and politics is supposed to be an expression of the general will of "the pure people". This positions populism in opposition to elitism and pluralism. In populist politics there are less spaces left for minorities and they are often presented as traitors to the real will of the nation or even marionettes of foreign powers.

The very core components of populism are highly flexible: the definition of the people, the imagined the other and the general, unified will. This triangle may take various shapes depending from the context. It also affects many important questions of democracy theory - the relation between the authorities and the governed, the legitimacy and representation question, as well as many other related issues on modes of decision making, redistribution mechanisms, relations with the international community, and so on.

The most common ways of understanding populism contain of its minimum components: "the good people" that is endangered by "the evil others". Such an alignment runs crosswise of established party lines and is in essence nativist. Such a definition of populism correlates with the general every day usage of this word whenever, usually for journalist purposes, we refer to a person, party, action or decision that makes claims by appealing to ordinary, non-elite people. In public discourse it is often used as a pejorative epithet implying that the accused is corrupt, cynical, opportunistic or even undemocratic. This opens the way to nativism, which seem to be a more moderate expression, however it contains the same common denominator as populism (understood as ideology). Unlike populism, nativism offers a narrative that sets up solidarity of the "common people" against the aliens predominantly. Populism is targeted much more against the elites.

The populism on the ground (as a thin-centred ideology) need to be supplemented with additional values and beliefs. By doing this it cohabits with other more comprehensive ideologies, depending on the context. This is why populism's power (and danger at the same time) lies in its chameleonic nature which is adapting its face according to the context and connecting itself to other political ideas or ideologies. As a consequence it is difficult

10 "Thin" due to the fact that its particular ideas are of limited scope, complexity and ambition, it is not a complete ideology in opposition to full ideologies, like: nationalism, socialism or liberalism. Michael Freeden explained a thin-centered ideology that is arbitrary in serving itself from wider ideational contexts, it flexibly removes or replaces some concepts, it lacks internal integrity and coherence (Freeden 1998).

11 There are however raising concerns about assigning populism's genus to ideology. The controversy on populism as an ideology stems from the fact that it falls short of the status of clear ideology. It went, as a concept, through a dynamic evolution, serving for various associations with fiscal irresponsibility (there is no uncontested clear line between responsibility and irresponsibility), neo-liberal extremism or xenophobic stances. It lacks a stable program (empty hearted ideology).

12 MUDDE, 543. 
to find one political arena free from populist actors, tactics or statements. We can identify agrarian populism, nationalistic populism, neoliberal populism, radical left-wing populism and so on. All of them contain the nativist gene.

\section{Nationalist manifestations of nativism}

Nationalism, psychologically understood, is a state of mind in which the individual identifies himself with the "we-group" to which he or she is loyal. Within the "we-group" prejudice and discrimination is generated by the real or hypothetical threat coming from some other "out-group". To justify the prejudice and discrimination, negative stereotypes of the "out-group" are developed (usually based on the perceived fear about the physical, social or economic health of the "in-group"). There is a number of social psychological works analyzing the link between authoritarian personality and the "in-group" - "out-group" orientations. They inform us that nationalism are highly and positively correlated with ethno-centrism, authoritarianism and conservatism as well as negatively correlated with internationalism. ${ }^{13}$ Mainstream politicians are increasingly adopting localism ${ }^{14}$ and the concept of authenticity as a framework for policy and politics making. This makes mainstream nationalism a projection and manifestation of nativist way of thinking.

Nationalism as a political slogan carries a strong - very often pejoratively associated connotation. Used as an epithet in public discourse, it usually means, protective, maybe even isolationist, aggressively oriented towards others policies, actions or rhetoric. Many scholars, especially those who deal with economy, still employ the term almost synonymously with mercantilism or protectionism. ${ }^{15}$ Using nativism, which is a much more friendly sounding term, neutralizes all the negative connotations of nationalism. Still, the essential components of both are dangerously similar. The xenophobic and ethno-nationalist frames that are employed that serve to construct meanings about the "other". The combination of differential nativism and comprehensive protectionism (defensive nationalism) seeks to exploit the anxieties and feelings of insecurity originating from the socio-economic determinants, like globalisation, transformation or crisis. ${ }^{16}$

Various disciplines suggest various explanations as regards the determinants of the far right, anti-migrant nationalism and populism. Socio-psychological factors include authoritarian personality traits and value orientations which are, in turn, associated with social disintegration coexistent with the times of radical change (like transformation, crisis, etc.). This way of thinking correlates with modernisation theory in which it is suggested that the rapid socio-economic change (post-communism, post-industrialisation, risk-society, etc.) makes individuals and groups aggressive and hostile. Rational choice logic points to the mechanism of scapegoating and group interest conflicts, suggesting that prejudice, dis-

13 BAUGHN, Christopher C. - YAPRAK, Attila: Economic Nationalism: Conceptual and Empirical Development, in: Political Psychology, 17, 1996, 4, 759-778.

14 WILLS, Jane: Populism, localism and the geography of democracy, in: Geoforum, 62, 2015, $188-189$.

15 SHULMAN, Stephen: Nationalist Sources of International Economic Integration, in: International Studies Quarterly, 44, 2000, 3, 365-390.

16 KLUKNAVSKÁ, Alena: Enemies among us: The anti-elitist and xenophobic discourses in the Czech Republic and Slovakia, in: Rexter - Časopis pro výzkum radikalismu, extremismu a terorismu, 2014, 2, 42-71. 
crimination and sometimes outright conflict is a natural result of competition over limited resources. Identity studies focus on perceived threats posed by migrants on the nation and its culture. Socio-structural models explain support for the populist far right by the aggregate level of immigration in a given country or locality (its height and the increasing trend), economic conditions (unemployment, wage levels) and the level of support for the political system (political discontent). Last but not least, it is the media that play a decisive role in formulating, especially young people's attitudes towards migrant and migration.

Young people's support for nationalist and far right ideology consists of negative attitudes towards minorities, xenophobia, welfare chauvinism and exclusionism in relation to migrants. Ethnic nationalism, financial problems and economic insecurity (perceived competition and pressure on socio-economic resources) belong to the most important factors behind the relatively high prevalence of anti-migrant sentiments. Additionally the scholarly research results show that low interest and poor understanding of politics, together with high exposure to media (which, instead of educating and dispelling prejudice, further worsen attitudes towards minorities and migrants) go hand in hand with accepting far right populist message. ${ }^{17}$

The economic aspect of nationalism needs to be emphasised in the context of nativist sentiments and their origins. Economic nationalism may also to be positioned very close to economic populism since nationalism is one of the ideologies that overlap and complement the thin-centered ideology of populism. It refers to the people understood as a nation as well as its economic interest and security. Especially together with the growing salience of economic security, the economic nationalism becomes and increasing component of nationalistic sentiment. It can be most simply understood as discrimination in favor of one's own nation. It is implemented in many various forms and measures, including policy implementation, protectionism, subsidizing domestic producers and service providers, regulatory burdens, export dumping, countervailing duties and many others. Economic nationalism may also take some more soft forms, like for example favoring local products and services by consumers' choices.

Defining economic nationalism as a promotion of given nation's autonomy, unity and interests, allows to argue that nationalists potentially may have strong motivations both for and against close economic ties with foreign economies. Depending on the international position of a given national economy, nationalists may need to make trade-offs and compromises in order to optimize their strategy and tactics. The nationalist calculus of independence and interdependence or integration does not always bring about protectionist outcomes. It is because of the interdependency of the economies and complexity of global economy as such that makes it impossible to separate by nationality.

Economic nationalism remains an important factor that mobilizes population around a state-sponsored economic vision. It can be economic nationalism of mineral resources, or protecting the local population from "free trade imperialism" of an economically powerful neighbor, or persuading the citizens to keep their own currency in order to preserve the rest of national sovereignty, or any other political-economic argument. It may be associated with economic patriotism of those buying local products and services instead of the

17 MIERIN,A, Inta - KOROL̦EVA, Ilze: Support for far right ideology and anti-migrant attitudes among youth in Europe: A comparative analysis, in: The Sociological Review, 63, 2015, 2, 183-205. 
global brands. Economic nationalism has many faces. No question, there are elements of nationalism and economic nationalism in all countries and economies. ${ }^{18}$ In Ukraine - nationalists promote closer ties with EU as a counterbalance to the alternative - the Russian domination. In Canada, free trade is supported as a way of reducing the central state's power. ${ }^{19}$ But generally it was defined in opposition to economic liberalism and therefore it means predominantly everything that the economic liberals do not like. This is also a reaction to the fact that economic nationalists built their position on criticizing liberal economic policies (free trade imperialism of the wealthy and powerful). In scholarly literature the phrase started to be used by international relations experts (increasingly widely in 1970s) as an economic variant of the ideology of realism. ${ }^{20}$

Economic nationalism so far has been regarded rather as a set of attitudes then a coherent theory, however some scholars argue ${ }^{21}$ that bringing the concept of nation into political economy may result into systematic theory of economic nationalism. Here however we are much more interested into the ideology of economic nationalism. It usually consists of protectionist and aggressive state intervention. ${ }^{22}$ Many of its elements are associated with the nativist way of thinking about the society and economy. It is the promotion of localism, protection of the interest of the domestic and the demonization of the alien influence. Just like populism and nationalism, nativism becomes more valid in times of crisis (like economic recession), migration pressure (flow of refugee or high concentration of migrants), terrorist attacks, wars, etc.

Populism, as well as nationalism and nativism, grow very fast on the fertile ground of political discontent. The populists, once strong, fuel the political discontent. ${ }^{23}$ It makes populism both the source and the consequence of political discontent. This mechanism creates a vicious circle of populism and political discontent that are intertwined with nationalism (usually of economic nature today) and nativism. This is crucially salient in the region of Central Europe, where the societies had to keep patient for almost one generation, first suffering the costs of socio-economic transformation and second as a subject to the pre-EU-accession conditionality. Once the strategic, geopolitical and geo-economic objectives (membership in the Western security and economic structures, like NATO or EU) were reached, the taboo of political correctness disappeared. The coincidence of the economic, migration, and other types of crisis stimulated further the discontent and therefore the populist and nationalist politics "exploded".

18 ISAACS-MARTIN, Wendy: National Identity and Economic Nationalism. Can an Economic Perspective Reinforce Nationalism and Nation Building?, in: Africa Insight, 41, 2011, 1, 59-70.

19 SHULMAN.

20 HELLEINER, Eric: Economic Nationalism as a Challenge to Economic Liberalism. Lessons from the $19^{\text {th }}$ Century, in: International Studies Quarterly, 46, 2002, 3, 307-329.

21 NAKANO, Takeshi: Theorising economic nationalism, in: Nations and Nationalism, 10, 2004, 3, $211-229$.

22 BEREND, Ivan: The Failure of Economic Nationalism. Central and Eastern Europe Before World War II, in: Revue économique, 51, 2000, 2, 315-322.

23 ROODUIJN, Matthijs - VAN DER BURG, Wouter - DE LANGE, Sarah: Expressing or fuelling discontent? The relationship between populist voting and political discontent, in: Electoral Studies, 43, 2016, 32-40. 


\section{Conclusion}

Despite of the fact that nativism has predominantly American origins, its manifestations have appeared all over the world in various forms and re-incarnations. Most recently, Europe - especially Central Europe - has become the battlefield between the liberal versus illiberal forces. Nativism positions itself at the core of the illiberal camp and in opposition to the main liberal values. The open announcement of the illiberal democracy and its wide acceptance among the Hungarian and Polish society represent only a manifestation of the tendencies present in the political sphere. In the realm of economy, liberal forces associated by Central Europeans as the foreign investors, International Monetary Fund or any other external powerful agents are treated with equal suspicion. As the result, the nativist way of thinking reveals itself in xenophobic attitudes, nationalism and ethnically based populism. Building on the discontent with neo-liberalism and widely-understood cosmopolitanism, the Central European version of nativism evolved into an important element of the mainstream political landscape.

Only on the surface, nativism looks as a friendly concept, especially when associated with localism, authenticity, patriotism and "our way of life". In fact, it shares many exclusivist, illusive and potentially destructive components with nationalism and populism. The advent of economic globalization and the perceived threat to national identities encourage the protection of local cultures, which takes the form of nationalism, tribalism or nativism. Some of the most intensive outbursts of nationalism may be observed in nations which have felt themselves exploited (post-colonialism) or have believed that the benefits of globalization are passing them (inequality problem). The feeling of unjust and instability is a fertile ground for religion, traditional culture, tribalism and ethnicity to step in. Secularism found itself in defense and has been targeted as an enemy. The same some other alien religions and ethnicities that are supposed to clash with ours. It coexists very often with self-victimization and messianicism. This kind of Zeitgeist is a fertile ground for the emergence of strong nativist movements. They coexist and intertwine with the related nationalism and populism - this article offers some conceptual ordering of the three overlapping terms.

In this article, the author claims that nativism is a close ally of nationalism, especially in its economic dimension, and populism - understood both as a thin-centred ideology as well as a political tactic. In the public discourse they are even sometimes used inter-exchangeably. In the academic literature they tend to be mixed and confused. In fact they are substantively related. Parts of their meaning overlap and parts remain distinct, however they seem to be more similar then different.

In relation to nationalism, nativism too correlates with xenophobic and racist sentiments. It is built on the assumption of homogeneous and united "people". It suggests protecting the interests of "the domestic" over the interests of "the other". The newcomers or minorities are treated unequally compared to the favoured status of the established inhabitants. Therefore both nationalism and nativism inspire discriminatory actions and rhetoric. It means the demonization of the strangers. The "outer group" is associated with mostly or exclusively negative stereotypes. The hegemony of the natives is supposed to stop the dangers of the outside influence. Therefore the nativist focus on indigenous customs (even at the cost of modernisation). 
At the same time, nativism does not share with nationalism the exclusive orientation on the nation as the only or main political community. It goes beyond that perspective, offering other criteria of the communitarian feeling or the "common sense". It may be in-born genetic make-up, but it can also be localism language or dialect, historical legacy or religion. Nationalism is in this sense much more reductionist but also offers much more developed ideology that spread globally.

The most obvious differentiating point between nativism and populism is the populist focus on elitism. For nativism "the ordinary people" are threatened by the newcomers. Whereas in the case of populism "the others" may be migrants, but equally often they are establishment, bankers, experts, intellectuals or any other members of the "imagined elite". The both concepts do not share the same definition of solidarity. Unlike populism, in which case it is anti-elitist mobilisation, nativists understand solidarity as the loyalty to the authentic people. The "imagined community" in this way is constructed in opposition to the non-natives.

However it shares a lot of similarities with populism. Historically speaking, the agrarian origins of both are symptomatic. In contemporary public discourse they both focus on anti-migrant narrative. Agrarian or xenophobic, they are both radical in form and they are both economically justified and determined. The critics of inequalities and the postulates of fair economic redistribution are present in both over time. The non-native elements are treated as a threat. They both use emotions, usually negative emotions like fear, prejudice or suspicion. Just like populism it is built on the contrast to cosmopolitanism or elitism. They are both illiberal concepts as they do not tolerate plurality of ideas, attitudes or actions. The "heartland people" need to be homogeneous and united. And the nativist way of thinking justifies policies oriented at protecting the interest of the native-born.

Nativism constitutes a dangerous ideology, potentially destructive at the levels equal to nationalism or populism. It is hidden behind the positive connotation of the word "native", whereas it contains the same poisonous essence (as in the case of nationalism): like to feeling of superiority over everything that is alien, exclusionism and - in more aggressive versions - protectionism or even xenophobia and racism. Nativism, nationalism and populism use simplistic, but therefore attractive and effective, argumentation referring to emotional and irrational rhetoric. They all mobilise the ordinary people and valorise their authenticity. Glorification of morally pure "commoners" resonates very well not only with the nationalist ideology or populist tactic but predominantly with the realm of nativist way of perceiving the world.

\section{References}

BAUGHN, Christopher C. -YAPRAK, Attila: Economic Nationalism: Conceptual and Empirical Development, in: Political Psychology, 17, 1996, 4, 759-778.

BEREND, Ivan: The Failure of Economic Nationalism. Central and Eastern Europe Before World War II, in: Revue économique, 51, 2000, 2, 315-322.

BLACK, John D.: The McNary-Haugen Movement, in: The American Economic Review, 18, $1928,3,405-427$.

DJERIOUAT, Hakim - TREMOLIERE, Bastien: We are made, not born: Empiricism is 
existentially useful, in: Motivation and Emotion, 38, 2014, 4, 529-539.

HELLEINER, Eric: Economic Nationalism as a Challenge to Economic Liberalism. Lessons from the $19^{\text {th }}$ Century, in: International Studies Quarterly, 46, 2002, 3, 307-329.

HIGHAM, John: Strangers in the Land: Patterns of American Nativism 1860-1925, New Brunswick 1955.

ISAACS-MARTIN, Wendy: National Identity and Economic Nationalism. Can an Economic Perspective Reinforce Nationalism and Nation Building?, in: Africa Insight, 41, 2011, 1, 59-70.

JANSEN, Robert S.: Populist Mobilisation: A New Theoretical Approach to Populism, in: Sociological Theory, 29, 2011, 2, 75-96.

KLUKNAVSKÁ, Alena: Enemies among us: The anti-elitist and xenophobic discourses in the Czech Republic and Slovakia, in: Rexter - Časopis pro výzkum radikalismu, extremismu a terorismu, 2014, 2, 42-71.

KNOBEL, Dale: America for Americans: The Nativist Movement in the United states, New York 1996.

LIPPARD, Cameron: Racist Nativism in the $21^{\text {st }}$ Century, in: Sociology Compass, 5, 2011, 7 , 591-606.

MIERINA, Inta - KOROLEVA, Ilze: Support for far right ideology and anti-migrant attitudes among youth in Europe: A comparative analysis, in: The Sociological Review, 63, 2015, 2, 183-205.

MUDDE, Cas: The Populist Zeitgeist, in: Government and Opposition, 39, 2004, 4, 542-543.

MUELLER, Jan-Werner: Parsing populism. Who is and who is not a populist these days?, in: Juncture, 22, 2015, 2, 80-89.

NAKANO, Takeshi: Theorising economic nationalism, in: Nations and Nationalism, 10, 2004, 3, 211-229.

ROODUIJN, Matthijs - VAN DER BURG, Wouter - DE LANGE, Sarah: Expressing or fuelling discontent? The relationship between populist voting and political discontent, in: Electoral Studies, 43, 2016, 32-40.

SHULMAN, Stephen: Nationalist Sources of International Economic Integration, in: International Studies Quarterly, 44, 2000, 3, 365-390.

STAVRAKAKIS, Yannis: The Return of the "People": Populism and Anti-Populism in the Shadow of the Europea Crisis, in: Constelations, 21, 2014, 4, 505-517.

WILLS, Jane: Populism, localism and the geography of democracy, in: Geoforum, 62, 2015, 188-189.

\section{Author}

dr hab. prof. UO Rafał Riedel

Instytut Nauk o Polityce i Adminstracji, Wydział Nauk o Polityce i Komunikacji Społecznej, Uniwersytet Opolski

Institute of Political Science and Administration, Faculty of Political Science and Social Communication, University of Opole ul. Katowicka 89, 45-061 Opole, Poland riedelr@wp.pl 